
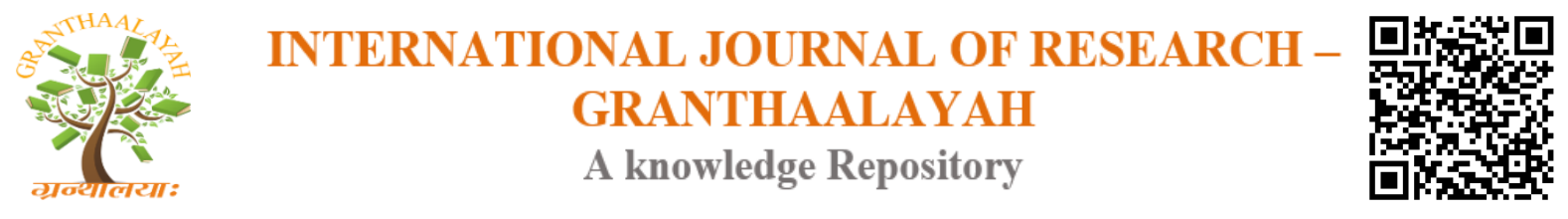

Social

\title{
ELABORATING TEACHING ENGLISH TO YOUNG LEARNERS COURSES WITH CREATIVE DRAMA: ALTERNATIVES FOR PROSPECTIVE TEACHERS
}

\author{
Dr. Ayfer SU BERGiL ${ }^{* 1}$, Ayşegül ERÇEVIK ${ }^{2}$, Gamze ERDEM ${ }^{3}$ \\ ${ }^{* 1}$ Department of Foreign Language Education, Amasya University, Amasya 05100, Turkey \\ ${ }^{2}$ Department of Educational Sciences, Amasya University, Amasya 05100, Turkey \\ ${ }^{3}$ Department of Foreign Language Education, Amasya University, Amasya 05100, Turkey
}

\begin{abstract}
The aim of this study is to teach creative drama techniques to Amasya University English Language Teaching Department students in the scope of Young Learners courses, enrich students' vision to perform different activities in practicum practices and observe its contributions to the course process. Four stages of creative drama, namely warm-up/relaxation activities, games, improvisation and evaluation were included in this research and supported as a project by the Scientific Research Commission of Amasya University. In this research the scale of attitudes towards creative drama, consisting of 50 items was adapted and used as a highlighting part of "Teaching English to Young Learners" course. As a method, namely qualitative research referring to both descriptive and phenomenological researches was used in the study. Moreover, to support the results of qualitative ones, the quantitative statistics of OneSample Kolmogorov-Smirnov Test, Wilcoxon Signed Rank Test for Paired Samples were applied to the collected data. Related to the obtained results, it was clearly seen that the teaching English to young learners courses should be enriched with creative drama activities in the process of teacher training and the prospective teachers need to be fostered using this kind of practices during their faculty education.
\end{abstract}

Keywords: Teaching English to Young Learners; Creative Drama; Teacher Training.

Cite This Article: Dr. Ayfer SU BERGIL, Ayşegül ERÇEVIK, and Gamze ERDEM. (2017). "ELABORATING TEACHING ENGLISH TO YOUNG LEARNERS COURSES WITH CREATIVE DRAMA: ALTERNATIVES FOR PROSPECTIVE TEACHERS." International Journal of Research - Granthaalayah, 5(12), 232-245.

\section{Introduction}

Considering the theoretical dimensions and general characteristics, it is inevitable not to see the relationship between creative drama and foreign language teaching. According to some researchers, teaching English simultaneously brings creative drama practices. For this reason, creative drama is seen as a powerful tool to improve individuals' communication abilities. 
Success of foreign language teaching practices is based on the conditions of use of the principles and methods within the class. Basic principles created in this direction are series of suggestions that are formed as a result of language and education scientists' study findings. These suggestions are key features for the teachers and educators who direct this process during foreign language teaching and learning practices. By planning and implementing a classroom interaction appropriate to the basic principles, efficiency in foreign language teaching can be mentioned.

Foreign language teaching consists functional integrity of listening, speaking, reading and writing. As mentioned before, one of the principles of foreign language teaching is to improve four basic language abilities. While teaching language as a communication tool, it is necessary to pay attention to four basic language abilities. Using creative drama in the process of foreign language teaching ensures that many activities towards improving these four language abilities are included in the resources. On the basis of the activities, goals targeted to basic skills such as expressing oneself by gaining critical thinking ability, improving imagination, emotions and thought, gaining experience on different events, cases and situations, embodying abstract concepts or experiences and finally gaining language and communication skills through the development of vocabulary are pursued (Fleming, 1995; McCaslin, 1990). In foreign language teaching, in class practices can be planned and practiced in parallel to these goals. Teaching the subjects to be taught in a certain order, teaching these subjects from simple to complex, from concrete concepts to abstract ones and thus being a sequence between subjects is one of the principles forming the language teaching program (Demirel, 1990, s. 24; 1997, s. 123). The content of the foreign language courses can be rearranged by planning some of the creative drama studies again as the course has the successive feature and topics should be taught over and over again as the time and place of the topics arrive.

In this context, in the organization of content of the foreign language course, photographs, paintings, sculptures, poems, stories, tales and music can be used to develop the four basic language skills mentioned above and if needed, the studies can be repeated on the basis of the skills considered to be attained.

As mentioned by Tricia Evans (1984, p. 28), maybe it will not be possible to teach students' something new by sparing time to creative drama. However, it is possible to prepare them to outside conditions by encouraging them to use their abilities. Thus, creative drama gives the opportunity to use the target language by confronting students with situations and events they may encounter in everyday life. Together with this, it is seen that English teaching and creative drama merge in many places when the suggestions of İpekboyayan (1994, p. 57-58) related to the effective and successful foreign language teaching is analyzed.

As a result, in our English lessons taught as a foreign language in our country, dissemination of creative drama activities bring qualities to increase hopes with respect to overcoming problems and providing opportunities for learning and teaching applications.

\subsection{Literature Review}

When the existing literature is investigated, studies especially related to teachers', prospective teachers' and students' affective characteristics are seen because of creative drama's 
characteristic properties. In addition, creative drama has taken part in the education system of Turkey through master and doctorate theses conducted in this area. Among these, the studies and theses of Wang (2017), Dwi Astuti Wahyu Nurhayati's (2016), Yolageldi \&Arikan (2011), Bulut-Y1lmaz (2010), Köylüoğlu (2010), Su-Bergil (2010), Demircioğlu (2008), Saraç (2007), Royka (2002), Ay (1997), Çebi (1996) and Aynal (1989) can be given as examples.

Wang (2017) studied drama with students in a Chinese Art College. The study included to college students which are in the same level of English language proficiency, comparatively lower than other college majors. Researcher choose four cartoons (Beauty and Beast, The Lion King, Kung Fu Panda and Zootopia), for them to recreate and play out as drama activities in communication class where English in used as a source of language. The analysis based on the participants' reflection indicated that using drama is an ideal and effective way to stimulate learners' interest and motivation, moreover; it improves their proficiency, enhances their skills of communication and cooperation and develops their many soft skills.

Dwi Astuti Wahyu Nurhayati's (2016) study included three data collection types: Observation, interview and documentation. Observation conducted steps, which created the learning community, script based on themes (romance, humor, folklore, horror, and legend), counseling the students' script (before performing drama) and observing students when they performed dramas outdoor. In documentation, drama scripts were data included in the study. In interview, researcher asked students about the technique. Most of students said the technique contributed to their speaking ability, writing skills (writing, willingness, concentration, imagination to create the script). Students also said that it improved their knowledge about conducting and performing characterization. It also increased their self-confidence to perform in front of other friends that it would help them to reduce their nervous to teach their students in the future.

Yolageldi \& Arıan (2011) designed a descriptive study with the aim to explore the beliefs and habits of Turkish EFL teachers' towards using games in young learners' English classes. Fifteen EFL teachers voluntarily participated in the study and in the selection of the participants, purposive sampling was used to get the most adequate data from the available individuals within the researchers' reach. A questionnaire was prepared by the researchers. The results of the first question showed that a great majority of EFL teachers, $86.67 \%$, believe in the pedagogical value of games in second language teaching. Question five asked participants whether it should be given a special role to the games in the foreign language teaching programme or not. The results of question five revealed that nearly all of the participants, $93.33 \%$, agreed with the idea that games should be attributed with a special role in the foreign language teaching programme. The results of question nine indicated that all of the participants share the same opinion that games provide learners with a chance to show their skills not only in grammar, but also in many areas of language. Lastly, thirteenth question was directed to learn whether participants think games as tools designed only for fun or alternatives that can be used to make instruction more effective. Results showed that while nearly half of the participants thought games as tools for fun, others thought them as one of the best alternatives to make the instruction beneficial for learners. The results reflected that most EFL teachers $(63.33 \%)$ do not agree with the idea that games prevent teachers from measuring students' knowledge of grammar when they are used as a form of instruction. Similarly, $56.67 \%$ of the teachers do not believe that games distract students' attention when they are used for teaching grammar. Sixty percent of the teachers disagree with 
the idea that using games in grammar classes is time-consuming. Question twelve indicates that most of the EFL teachers, $86.67 \%$, have difficulty in finding a game for every field of grammar. In conclusion, the results reveal that while most of the EFL teachers still believe in the validity of teaching direct rules, their attitudes towards the use of games as a form of instruction are generally positive. The results of question three signal that a great majority of EFL teachers, $93.3 \%$, believe that games lower students' anxiety towards grammar learning. Therefore, games help students overcome their anxiety, feel relaxed and be enthusiastic to learn. Question four reveals that most of the EFL teachers $(76.67 \%)$ believe that games are effective in grammar teaching. Question seven shows that the important part of the teachers, 93.3\%, agrees with the idea that grammar games encourage, entertain and promote fluency. Question eleven reveals that a great majority of teachers, $86.7 \%$, think that games are motivating and entertaining way of teaching grammar, especially for weak students. Question fifteen was directed to the participants to reveal how frequent they use games in their EFL classes to teach grammar. The results indicate that many of the participants, $63.33 \%$, try to use games as much as possible in their classes, however; one can conclude from the results that games are not used so frequently as expected in EFL classes because the result is low in percentage when compared with the results of other questions.

In a study conducted by Bulut-Y1lmaz (2010), effects of creative drama activities on vocabulary learning was investigated. During 8 weeks of study, experimental group worked on various creative drama activities. At the end of the study, control and experimental group took Attitude Measurement Survey of Gardner (1985) besides vocabulary success test. In addition, after every drama lesson, students' perception towards creative drama was measured with evaluation chart. Results of the study indicated that there was a significant difference between control and experimental groups with respect to vocabulary learning.

In addition, in the thesis named as "Using Drama in Teaching English for Young Learners" Köylüoğlu (2010) separated participants as experimental and control group. During the study, experimental group learned the Simple Present Tense with creative drama and control group learned the same topic with traditional methods. The results of pre and post tests indicated that students who learned the topic with creative drama was more successful compared to the students in the control group. Moreover, the study of Su-Bergil (2010) investigated the impact of a creative drama technique in improving speaking abilities of university level preparatory class students. There were control and experimental group in the study. Traditional and creative drama techniques were used to teach vocabulary and effectiveness of creative drama techniques were studied. Results of the study indicated that compared to traditional techniques, creative drama techniques were more effective to teach speaking abilities to classes in which English is taught as a foreign language.

Demircioğlu $(2008 ; 2010)$ studied with $9-10$ year old students studying at the $3^{\text {th }}$ grade. In study there were two groups defined as an experimental and a control group. Five lessons prepared in order to teach new vocabulary item through drama. On the other hand, the students in the control group learned new words, but the teacher gave only the Turkish equivalents of the words or showed the pictures and they just followed the book in a traditional way. They did not participate in any drama activities. In the analysis of the data regarding the variables examined in this research, the following findings were obtained. First of all, a significant difference was 
observed between the arithmetic means of the groups' posttests scores in favor of the experimental group. With $95 \%$ degree of confidence $(\mathrm{p}<.05)$ level, there existed significant difference between the experimental and control group. Only two of twelve scores showed that there was not a significant difference between the groups because of the topics (collections and animals) the students were familiar with. Thus, a significant difference was observed between experimental and control group except for only two of twelve scores related with collections and animals topics.

In parallel to these studies, Saraç (2007) investigated the use of creative drama in improving children's speaking abilities. Participants of the study were 25 students who were students at the Pakistani Embassy International Study Group School in which the children of approximately 36 countries are located. Children were between the ages of 7-9 and they were coming from different socio-economic backgrounds with different English levels. For this purpose, 8 lessons were conducted, recorded and watched by the researcher. In addition, students wrote on their diaries about their creative drama practices to learn more about their expectations, emotions and thoughts about creative drama. Observed lesson and student diaries were evaluated to interpret the data. It was seen from the observed lesson that speaking ability of students increased and the diaries indicated that creative drama had a positive effect on students' self-confidence, presented a stress free learning environment and thus, students' participation to the lesson increased.

Royka (2002) stated that teachers are reluctant to use 'drama' activities in classrooms for various reasons: they don't know how to use the activities, limited resources, time constraints, a fear of looking and feeling foolish and the list goes on. Generally these feelings are more prevalent when attempting to use drama with adults. Teachers of young children tend to use more play, games and drama type activities since the children are closer to the "play and explore" stage of development. Often children are much more receptive to any kind of "make-believe" or drama type activity. Of course this is not always the case and it would depend on the cultural values, the ability of the children, and varying social factors. In the study of Overcoming the fear of using drama in English Language Teaching Royka (2002) concentrated on the reluctance that was observed in language teachers of adults when drama activities were introduced to them.

Moreover, Ay (1997) also studied the use of creative drama in foreign language teaching in his master thesis. Examples were given with respect to how creative drama can be used in English lessons and investigated the effect of examples on students' language improvement.

The doctorate thesis of Çebi (1996) named as "Development of Imaginary Language Ability through Creative Drama for Teaching Purposes" focused on the imaginative language and creative drama interaction and investigated the effect of this interaction on improving students' language skills. In addition, Aynal (1989) studied the effect of dramatization method on language learning and found out that dramatization method was more effective in the third grade primary level English lessons compared to traditional ways.

When the existing literature was considered, it was seen that creative drama was not seen as lesson content in the undergraduate program of English Language Teaching but studies were conducted as it was believed that it influenced prospective teachers' teaching practices after graduation. Therefore, this study was significant in investigating the effect of creative drama on 
the content of the course "Teaching English to Young Learners" that undergraduate English Language Teaching department students took and preparing teacher candidates to real life teaching environment.

\section{Materials and Methods}

\subsection{Method}

The method part contains information related to the design, participants, data collection instrument, and data collection and analysis procedures of this research.

\subsection{Design}

In the research, it was aimed to put through a mixed type research which is defined as combining quantitative and quantitative methods, approaches and concepts in a specific or following research by a researcher (Creswell, 2003; Tashakkori ve Teddlie, 1998; Johnson \& Onwuegbuzie, 2004). Since the mixed method provides different points of views via applying various methods to the circumstances, it also supplies positives aspects to the analysis and combining procedures (Johnson \& Turner, 2003). Moreover, as Creswell (2006) states "collecting multi-data via different strategies, methods and approaches by a researcher which is one of the basic principles of mixed method, helps researchers comprehend the problems profoundly with the combination of qualitative and quantitative methods compared to the researches carrying out only one method in their data analysis process.

\subsection{Participants}

Eighteen English as a foreign language prospective teachers registered to English Language Education Department of Amasya University voluntarily participated in this study in the Fall and Spring Semester of 2016-2017 academic year. No selection of the participants was done because of the limited number of participants taking "Teaching English to Young Learners" Course but 2 of the participants were excluded from the study since their data were not valid in detail. The participants ranged in age from:

Table 1: Age Distribution of the Participants

\begin{tabular}{|c|c|c|}
\hline Age & $\boldsymbol{f}$ & $\boldsymbol{\%}$ \\
\hline 20 & 3 & 16.7 \\
\hline 21 & 8 & 44.4 \\
\hline 22 & 4 & 22.2 \\
\hline 23 & 1 & 5.6 \\
\hline 26 & 1 & 5.6 \\
\hline 33 & 1 & 5.6 \\
\hline Total & 18 & 100.0 \\
\hline
\end{tabular}

According to the age distribution of the participants, it has shown that most of the prospective teachers to whom the creative drama sessions were applied ranged between 20 and 22. In detail, 
3,8 and 4 prospective teachers range in 20,21 and 22 with the percentage of 16.7, 44.4 and 22.2 representing the $83.3 \%$ of the total population.

Table 2: Gender Distribution of the Participants

\begin{tabular}{|l|l|l|}
\hline Gender & $\boldsymbol{f}$ & \% \\
\hline Female & 14 & 77.8 \\
\hline Male & 4 & 22.2 \\
\hline Total & 18 & 100.0 \\
\hline
\end{tabular}

Parallel to the gender distribution of the participants, it has been demonstrated that 14 prospective teachers out of 18 with $77.8 \%$ were females and 4 of them with $22.2 \%$ were males. In terms of the gender distribution, the inclinations of the female prospective teachers were accepted as normal because of the preference of English Language Teaching department by students.

\subsection{Data Collection Instrument}

The scale of attitudes towards creative drama, consisting of 50 items, was adapted from Adigüzel (2006) who designed the scale for the students taking creative drama course in 2005-2006 academic year. In this research the scale was adapted for the purpose of reaching attitudes towards creative drama used as a highlighting part of "Teaching English to Young Learners" course. This 50 -item scale appears into a 5 point likert type scale ranging from " $1=$ Totally disagree", "2= Disagree", "3= Neutral", "4= Agree", and "5= Totally agree". Depending upon the scale of attitudes towards creative drama, the following questions were applied to the collected data:

- What are the attitudes of prospective EFL teachers towards creative drama?

- Is there significant difference of prospective EFL teachers' attitudes towards creative drama?

- How effective are creative drama activities in the process of teaching English as a foreign language?

- Is there significant difference of creative drama activities in the process of teaching English as a foreign language course?

\subsection{Data Collection and Analysis Procedures}

The gathered data was coded and analyzed via SPSS 20.00 package program for social sciences. Since the time limitation and the difficulty of practicing creative drama in large groups made it impossible for researcher to administer the practices to a larger sample. By the way, the researcher made use of convenience sampling method in the present research study as the number of the participant is limited to 18 in number. Therefore, non-parametric methods were applied to the gathered information in the statistical part of the research. 


\section{Results and Discussions}

Table 3: Statistics of Creative Drama Scores

\begin{tabular}{|l|l|l|}
\hline $\mathbf{N}$ & Valid & 18 \\
\cline { 2 - 3 } & Missing & 0 \\
\hline Mean & 205.61 \\
\cline { 2 - 2 } $\begin{array}{l}\text { Median } \\
\text { Mod }\end{array}$ & 212.00 \\
\cline { 2 - 2 } $\begin{array}{l}\text { Std. Deviation } \\
\text { Minimum }\end{array}$ & 217.00 \\
\cline { 2 - 2 } $\begin{array}{l}\text { Maksimum } \\
\text { Sum }\end{array}$ & 14.93 \\
\cline { 2 - 3 } & 241.00 \\
\cline { 2 - 2 } & 3701.00 \\
\hline
\end{tabular}

The overall creative drama scores of English as a foreign language prospective teachers range from 144 to 241 which means that there is no homogeneity also in the creative drama levels of EFL teachers taking the same course.

Table 4: Frequencies of Creative Drama Scores Related to the Attitude Scale

\begin{tabular}{|l|l|l|l|l|l|}
\hline Score & $\mathbf{f}$ & \% & Valid\% & Cumulative\% & Score \\
\hline Valid & 144.00 & 1 & 5.6 & 5.6 & 5.6 \\
\cline { 2 - 6 } & 166.00 & 1 & 5.6 & 5.6 & 11.1 \\
\cline { 2 - 5 } & 167.00 & 1 & 5.6 & 5.6 & 16.7 \\
\cline { 2 - 5 } & 176.00 & 1 & 5.6 & 5.6 & 22.2 \\
\hline 187.00 & 1 & 5.6 & 5.6 & 27.8 \\
\cline { 2 - 5 } & 198.00 & 1 & 5.6 & 5.6 & 33.3 \\
\cline { 2 - 5 } & 202.00 & 1 & 5.6 & 5.6 & 38.9 \\
\hline 204.00 & 1 & 5.6 & 5.6 & 44.4 \\
\cline { 2 - 5 } & 207.00 & 1 & 5.6 & 5.6 & 50.0 \\
\cline { 2 - 5 } & 217.00 & 2 & 11.1 & 11.1 & 61.1 \\
\hline 218.00 & 1 & 5.6 & 5.6 & 66.7 \\
\cline { 2 - 5 } & 225.00 & 1 & 5.6 & 5.6 & 72.2 \\
\cline { 2 - 5 } & 227.00 & 1 & 5.6 & 5.6 & 77.8 \\
\cline { 2 - 5 } & 232.00 & 1 & 5.6 & 5.6 & 83.3 \\
\cline { 2 - 5 } & 234.00 & 1 & 5.6 & 5.6 & 88.9 \\
\cline { 2 - 5 } & 239.00 & 1 & 5.6 & 5.6 & 94.4 \\
\cline { 2 - 5 } & 241.00 & 1 & 5.6 & 5.6 & 100.0 \\
\cline { 2 - 5 } & Total & 18 & 100.0 & 100.0 & \\
\hline
\end{tabular}

Regarding to the frequencies of the prospective teachers' creative drama scores, in detail 10 of the participants' creative drama levels are higher than 205.61 however 8 of them are lower than that mean value. As seen in the frequencies of creative drama scores of attitude scale, there is no accumulation in a specific value except the value of 217 which provides and represents 2 of the participants in the research. 
Table 5: One-Sample Kolmogorov-Smirnov Test

\begin{tabular}{|c|c|c|}
\hline & Creative Drama Scores \\
\hline \multicolumn{2}{|l|}{$\mathrm{N}$} & 18 \\
\hline \multirow[t]{5}{*}{ Normal Parameters ${ }^{\mathrm{a}, \mathrm{b}}$} & Mean & 205.61 \\
\hline & Std. Deviation & 27.93 \\
\hline & Absolute & .158 \\
\hline & Positive & .103 \\
\hline & Negative & -.158 \\
\hline \multicolumn{2}{|c|}{ Kolmogorov-Smirnov Z } & .671 \\
\hline \multicolumn{2}{|l|}{ Asymp. Sig. (2-tailed) } & .758 \\
\hline
\end{tabular}

Referring to the statistics of creative drama scores and frequencies of creative drama scores related to the attitude scale, one-sample Kolmogorov-Smirnov test results present that the collected data were distributed normally in that they ranged in homogeneity and coherently which enables basis for the statistics procedures of this study.

Table 6: Wilcoxon Signed Rank Test for Paired Samples Results in Terms of the Creative Drama Scores of Prospective EFL Teachers

\begin{tabular}{|l|l|l|l|l|l|l|}
\hline Exam & Ranks & $\mathbf{N}$ & Mean Rank & Sum of Ranks & $\mathbf{z}$ & $\mathbf{p}$ \\
\hline \multirow{3}{*}{ Mid1 - Mid2 } & Negative Rank & $2^{\mathrm{a}}$ & 2.00 & 4.00 & 3.55 & .000 \\
\hline & Positive Rank & $16^{\mathrm{b}}$ & 10.44 & 167.00 & & \\
\cline { 2 - 8 } & Ties & $0^{\mathrm{c}}$ & & & & \\
\cline { 2 - 8 } & Total & 18 & & & & \\
\hline \multirow{5}{*}{ F-Mid2 } & & & & & \\
\cline { 2 - 8 } & Negative Rank & $1^{\mathrm{a}}$ & 5.00 & 5.00 & & \\
\cline { 2 - 8 } & Positive Rank & $17^{\mathrm{b}}$ & 9.76 & 16.00 & & \\
\cline { 2 - 8 } & Ties & $0^{\mathrm{c}}$ & & & & \\
\hline
\end{tabular}

As for the Wilcoxon Signed Rank Test for Paired Samples Results in Terms of the Creative Drama Scores of Prospective EFL Teachers, under the scope of the creative drama practices prospective EFL teachers' $1^{\text {st }}$ mid-term and $2^{\text {nd }}$ mid-term scores $(z=3.55, p<.05)$ differ significantly from each other as their final and $2^{\text {nd }}$ mid-term scores differ meaningfully $(\mathrm{z}=3.50$, $\mathrm{p}<.05)$. The obtained results have shown that there is no significant difference between prospective EFL teachers' final and $1^{\text {st }}$ mid-term exams statistically.

Table 7: Attitude Scale towards Creative Drama

\begin{tabular}{|c|c|c|c|c|c|}
\hline Items of Attitude Scale towards Creative Drama & 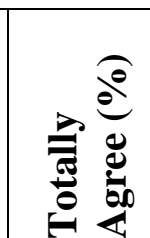 & 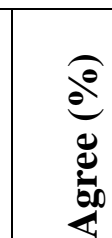 & 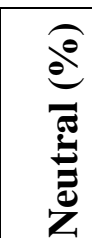 & 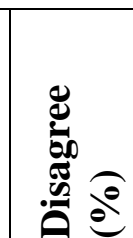 & 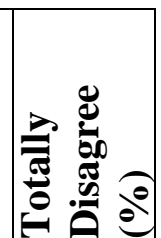 \\
\hline 1. I do not like creative drama. & .0 & 5.6 & .0 & 22.2 & 72.2 \\
\hline 2. I do not think that creative drama leads positive & 61.1 & 33.3 & .0 & .0 & 5.6 \\
\hline
\end{tabular}


DOI: 10.5281/zenodo.1134567

changes on participants' behavior.

3. I do not think that creative drama leads changes on me.

4. Expressing sensations during creative drama is disturbing.

\begin{tabular}{|l|l|l|l|l|}
\hline & & & & \\
\hline 61.1 & 22.2 & 11.1 & .0 & 5.6 \\
\hline 50.0 & 33.3 & 16.7 & .0 & .0 \\
\hline
\end{tabular}

5. Creative drama improves participants' imagination.

6. Creative drama improves participants' verbal communication skills.

7. Creative drama improves participants' selfexpression abilities.

8. Participants do not like to be asked what they feel after creative drama practices.

9. Creative drama do not increase the ability to use body language effectively.

10. After creative drama, participants behave more democratic.

11. Creative drama improves the one's selfconfidence.

12. Creative drama boosts one's self esteem.

$66.7 \quad 27.8$

13. Creative drama improves one's empathy abilities.

14. Creative drama enables one's to see the events from different perspectives.

15. People get ashamed of impersonation during creative drama.

16. Creative drama enables one to recognize other gender better.

17. Creative drama enables one to accept others' presence.

18. People join creative drama process willingly.

19. I think, people gain social sensitivity with creative drama.

$72.2 \quad 22.2$

\begin{tabular}{|l|l|}
\hline 72.2 & 27.8 \\
\hline 16.7 & 33.3 \\
\hline
\end{tabular}

20. Creative drama enables people to be more tolerant. 61.1

21. People have difficulty in focusing their attentions

in creative drama.

22. Creative drama does not contribute one's socialization.

\begin{tabular}{|l|l|l|l|l|}
\hline 16.7 & 33.3 & 22.2 & 22.2 & 5.6 \\
\hline 44.4 & 50.0 & .0 & 5.6 & .0 \\
\hline 61.1 & 27.8 & .0 & 5.6 & 5.6 \\
\hline 50.0 & 33.3 & 11.1 & 5.6 & .0 \\
\hline 66.7 & 27.8 & .0 & 5.6 & .0 \\
\hline 27.8 & 27.8 & 22.2 & 22.2 & .0 \\
\hline 50.0 & 38.9 & 11.1 & .0 & .0 \\
\hline 66.7 & 22.2 & 5.6 & 5.6 & .0 \\
\hline
\end{tabular}


DOI: 10.5281/zenodo.1134567

creative drama.

29. In programs, it should be given a few years not just

one term for creative drama process and practices.

30. I suppose that participants design authentic drama sessions after creative drama.

31. I suppose that time spared to creative drama is a

waste of time.

32. There should be a place for creative drama in every stage of education.

33. Creative drama is directly related to life.

34. I think, creative drama affects people's

relationships positively.

35. Warm-up activities in creative drama are not so important.

36. I believe in the necessity of impersonations

performed in creative dramas.

37. Sharings which aim evaluation in creative drama

are boring.

38. I think, relaxation practices in creative drama are

not effective.

39. Working in collaboration during creative drama process disturbs participants.

40. I think, creative drama process does not affect

participants' daily lives.

41. Creative drama enables to form public

consciousness.

42. Homework and tasks given in creative drama are

boring.

43. Every situation faced in life can be handled during creative drama process.

44. Creative drama can be taught as an extracurricular activity, there is no need to place it as a different course in the program.

45. Active participation is not important in creative drama.

46. I want to perform academic studies in the field of creative drama in the future.

47. I follow/read publications related to creative drama.

48. Creative drama practices in different occupation groups do not interest me.

49. Creative drama is a discipline on its own.

50. I find the relationship of creative drama with different disciplines important.

\begin{tabular}{|c|c|c|c|c|}
\hline 50.0 & 33.3 & 0 & 16.7 & .0 \\
\hline 33.3 & 27.8 & 38.9 & .0 & .0 \\
\hline 44.4 & 44.4 & 5.6 & 5.6 & .0 \\
\hline 44.4 & 38.9 & 5.6 & 11.1 & .0 \\
\hline 44.4 & 50.0 & 5.6 & .0 & .0 \\
\hline 61.1 & 27.8 & 5.6 & 5.6 & .0 \\
\hline 61.1 & 16.7 & 16.7 & 5.6 & .0 \\
\hline 44.4 & 33.3 & 11.1 & 11.1 & .0 \\
\hline 38.9 & 22.2 & 16.7 & 16.7 & 5.6 \\
\hline 50.0 & 44.4 & 0 & 5.6 & .0 \\
\hline 44.4 & 38.9 & 11.1 & 5.6 & .0 \\
\hline 44.4 & 33.3 & 0 & 22.2 & .0 \\
\hline 27.8 & 44.4 & 22.2 & .0 & 5.6 \\
\hline 27.8 & 33.3 & 11.1 & 11.1 & 16.7 \\
\hline 22.2 & 33.3 & 27.8 & 11.1 & 5.6 \\
\hline 22.2 & 27.8 & 16.7 & 27.8 & 5.6 \\
\hline 44.4 & 38.9 & 11.1 & .0 & 5.6 \\
\hline 11.1 & 22.2 & 16.7 & 33.3 & 16.7 \\
\hline 11.1 & 22.2 & 27.8 & 16.7 & 22.2 \\
\hline 27.8 & 27.8 & 22.2 & 16.7 & 5.6 \\
\hline 50.0 & 27.8 & 11.1 & 11.1 & .0 \\
\hline 38.9 & 50.0 & 5.6 & 5.6 & .0 \\
\hline
\end{tabular}


The results of attitudes scale towards creative drama were categorized into three parts such as the samples of general attitudes toward creative drama, effects of creative drama on individuals and finally effects of creative drama on teaching. The samples of these categories are presented in the following which represents the overall reached results of prospective EFL teachers' attitudes towards creative drama:

Samples of General Attitudes toward Creative Drama "I like creative drama." ( $\mathrm{N}=13$ Totally Agree, $\mathrm{N}=4$ Agree, $\mathrm{N}=1$ Disagree)

"Creative drama is an enjoyable process.", ( $\mathrm{N}=9$ Totally Agree, $\mathrm{N}=7$ Agree, $\mathrm{N}=2$ Neutral)

Samples for the Effects of Creative Drama on Individuals

"Creative drama improves participants' verbal communication skills." ( $\mathrm{N}=13$ Totally Agree, $\mathrm{N}=4$ Agree, $\mathrm{N}=1$ Totally Disagree)

"Creative drama improves the one's self-confidence." "Creative drama boosts one's self esteem.' ( $\mathrm{N}=10$ Totally Agree, $\mathrm{N}=7$ Agree, $\mathrm{N}=1$ Neutral)

Effects of Creative Drama on Teaching

"I do not believe that creative drama can be used as a teaching method in other lessons.' $(\mathrm{N}=12$ Totally Disagree, $\mathrm{N}=5$ Disagree, $\mathrm{N}=1$ Agree)

"In programs, it should be given a few years not just one term for creative drama process and practices.' ( $\mathrm{N}=9$ Totally Agree, $\mathrm{N}=6$ Agree, $\mathrm{N}=3$ Disagree)

"There should be a place for creative drama in every stage of education." ( $N=8$ Totally Agree, $\mathrm{N}=9$ Agree, $\mathrm{N}=1$ Neutral)

\section{Conclusions and Recommendations}

The present study investigated prospective EFL teachers' attitudes towards creative drama via an adapted scale and semi-structured interview questions. The results of the study revealed that the majority of prospective EFL teachers have knowledge about the creative drama and voluntarily will use the techniques it offers to them in their future profession. The results of this study also unearthed that being aware of the techniques of the creative drama can also facilitate and develop EFL teachers' competency levels of teaching.

Moreover, creative drama is a reflective tool which gives not only deep information about the prospective EFL teachers but also the program and the courses they got during their teacher education in English Language Teaching Departments. In this sense, creative drama should be taken into account in English language teacher education programs and as obligatory or elective and it should be incorporated/ integrated into English language teacher education curriculum.

Drama offers a unique experience in that it uses fictional situations and people, creating an opportunity to be and to do. Because drama is group art, everyone is invited to take part. It is very important in the classroom, especially for young learners not to be left out and be the part of the activities being done in the classroom and creative drama offers this opportunity. Class participation and learner motivation is usually at its highest level in the creative drama classroom as it was witnessed in this research. 
Furthermore, it was observed that the creative drama activities have expanded prospective EFL teachers' awareness of their own talk, enabled them to look at reality through fantasy, to see below the surface of actions to their meanings. This fact has provided an opportunity for the students of these teachers to adapt themselves to the meaningful context and produce unscripted and creative talk.

As a result, this study reveals and supports the idea that creative drama provides a common basis for the teaching competences regarding to Teaching English to Young Learners. It creates a stress free environment and motivated classroom where students feel more confident and willing to participate. Thus, the integrative potential of drama provides good return on investment for the time spent, and this may be critical when there is so much curriculum to cover in such a short time.

This small scale study of 18 prospective EFL teachers could be repeated with different participants of other universities or countries including a control group to generalize the findings and provide opportunity to reveal the effectiveness of creative drama practices or similar different contemporary applications which may be handled in EFL teacher education process. This point or other suggested opinions could be the topic of several studies and give inspiration for the distinctive applications which should be incorporated not only specifically to EFL teacher education but also generally to teacher education field.

\section{Acknowledgements}

We gratefully acknowledge the funding received by the Scientific Research Commission of Amasya University which supported us to accomplish and obtain the findings of this research.

\section{References}

[1] Adıgüzel, H. Ö., Oyun ve yaratıcı drama ilişkisi, (Yayınlanmamış Doktora Tezi), Ankara Üniversitesi, Eğitim Bilimleri Enstitüsü, Ankara, 1993.

[2] Adıgüzel, H. Ö., Eğitimde yeni bir yöntem ve disiplin: (Ed. H. Ö. Adıgüzel) Yaratıcı drama 19851995 Yazılar, Ankara: Naturel Kitap Yayıncılık, 2002.

[3] Adıgüzel, H. Ö., Yaratıcı drama kavramı, bileşenleri ve aşamaları, Yaratıcı Drama Dergisi, 1 (1), 2006, 17-29.

[4] Adıgüzel, H. Ö., Yaratıcı drama derslerine (Okulöncesinde drama ve ilköğretimde drama) ilişkin tutum ölçeğinin geliştirilmesi, Yaratıcı Drama Dergisi, 1 (2), 2006, 7-15.

[5] Ay, S. O., Yabancı dil öğretiminde dramanın kullanımı, (Yayınlanmamış Yüksek Lisans Tezi), Ankara Üniversitesi, Sosyal Bilimler Enstitüsü, Ankara, 1997.

[6] Aynal, S., Dramatizasyon yönteminin yabancı dil öğretimi üzerine etkisi, (Yayınlanmamış yüksek lisans tezi), Çukurova Üniversitesi, Sosyal Bilimler Enstitüsü, Adana, 1989.

[7] Bulut-Yılmaz, B., Çocukların kelime ediniminde yaratıcı drama çalışmalarının etkileri üzerine bir araştırma: Bir örnek-olay incelemesi, (Yayınlanmış yüksek lisans tezi), Gaziantep Üniversitesi, Sosyal Bilimler Enstitüsü, Gaziantep, 2010.

[8] Çebi, A., Öğretim amaçlı yaratıcı drama yoluyla imgesel dil becerisinin geliştirilmesi, (Yayımlanmamış doktora tezi), Ankara Üniversitesi, Sosyal Bilimler Enstitüsü, Ankara, 1996.

[9] Demircioğlu, Ş., Procedia Social and Behavioral Sciences, 2010, 439-443.

[10] Demircioğlu, Ş., Teaching English vocabulary to young learners via drama, (Yayınlanmış yüksek lisans tezi), Gazi Üniversitesi, Eğitim Bilimleri Enstitüsü, Ankara, 2008. 
[11] Demirel, Ö., Yabancı dil öğretimi ilkeler, yöntemler, teknikler, Ankara: Usem Yayınları, 1990.

[12] Demirel, Ö., Kuramdan uygulamaya eğitimde program geliştirme, Ankara: Usem Yayınları, 1997.

[13] Dora To, LW., Chan, Y.I.P, Lam, Y.K. \& Tsang, S.K. Y., Reflections on a primary school teacher professional development programme on learning English through process drama, The Journal of Applied Theatre and Performance, 16 (4), 2011, 517-539.

[14] Ellis, G.,'Young learners': clarifying our terms, ELT Journal, 68 (1), 2014, 75-78.

[15] Ersöz, A., Teaching English to young learners, Ankara: Karanfil Academy, 2016.

[16] Evans, T., Drama in English teaching, London: Croom Helm., 1984.

[17] Fleming, M., Starting drama teaching, London: David Fulton Publishers, 1995.

[18] Gardner, R.C., The attitude/motivation test battery (Technical report), London, Ontario, Canada: University Of Western Ontario, 1985.

[19] İpekboyayan, S., Yabancı dil öğretimiyle ilgili temel tavsiyeler. Dil Dergisi, 21, 1994, 57-58.

[20] Köylüoğlu, N., İngilizce öğretiminde çocuklar için drama kullanımı, (Yayınlanmış yüksek lisans tezi), Selçuk Üniversitesi, Eğitim Bilimleri Enstitüsü, Konya, 2010.

[21] Mccaslin, N., Creative drama in the classroom, New York: Longman, 1990.

[22] Nurhayati, D. A. W., Using local drama in writing and speaking:EFL learners' creative expression, Journal of English Language Teaching and Linguistics, 1 (1), 2016, 51-77.

[23] Royka, J.G., Overcoming the fear of using drama in English Language Teaching, The Internet TESL Journal, 8 (6), 2002.

[24] Saraç, G., The use of creative drama in developing the speaking skills of young learners, (Yayınlanmış yüksek lisans tezi), Gazi Üniversitesi, Eğitim Bilimleri Enstitüsü, Ankara, 2007.

[25] Su-Bergil, A., İngilizce öğretiminde konuşma becerilerini geliştirmeye yönelik alternatif bir teknik: Yaratıcı drama, (Yayınlanmış yüksek lisans tezi), Gaziosmanpaşa Üniversitesi, $\quad$ Eğitim Bilimleri Enstitüsü, Tokat, 2010.

[26] Wang, P., The use of drama in English teaching of Chinese art colleges, Journal of arts and Humanities, 6 (7), 2017, 48-54.

[27] Yolageldi, G. \& Arıkan A., Effectiveness of using games in teaching grammar to young learners, Elementary Education Online, 10 (1), 2011, 219-229.

*Corresponding author.

E-mail address: ayfer_su@yahoo.com.tr 